\title{
Does company size and profitability affect corporate social responsibility disclosure?
}

\author{
Rukaanisy Syahierah ${ }^{1}$, Ashilla Larasati ${ }^{2}$ \\ ${ }^{1}$ Faculty of Economics, Islamic University of Indonesia, Indonesia \\ 2Saxion University of Applied Sciences, Netherland \\ *Correspondent author: rukaanisy@yahoo.com
}

Article History

Received, 6 April 2019

Revised 1, 28 April 2019

Revised 2, 3 May 2019

Accepted, 20 May 2019

\begin{abstract}
Purpose: This research is aimed to analyze whether disclosure of corporate social responsibility (CSR) of sharia bank in Indonesia is influenced by some factors.

Methodology: This research used the data from Islamic Social Reporting (ISR) index. ISR was evaluated based on content analysis; that is by analyzing annual report of 11 sharia banks.
\end{abstract}

Findings: Multiple regressions showed that company size significantly affected the level of disclosure of CSR but it was the contrary for profitability.

Originality/contributions: This is the first study to used 11 sharia banks in Indonesia during the period of 2010-2013.

Keywords: Company Size, Disclosure of corporate social responsibility, Islamic Social Reporting, Profitability.

Cite this:

Syahierah, R. \& Larasati, A. (2019). Does company size and profitability affect corporate social responsibility disclosure?. Asian Journal of Islamic Management, 1(1), 38-50. DOI: 10.1108/AJIM.vol1.iss1.art4

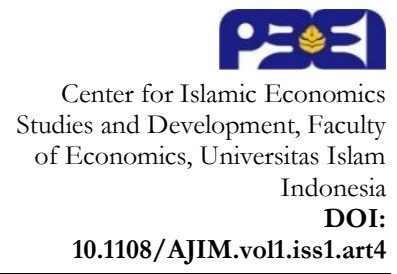

\section{Introduction}

With Islamic economic development nowadays, Islamic banking or sharia banking has been strengthened in various sectors of public life (Arifin and Nasution, 2015). Islamic banking adopts Islamic law or sharia law which has become a substantial part in financial service industry and has been growing significantly from size and structure in across the world, especially in emerging markets which have vast majority of Muslim population such as Indonesia. Therefore, sharia banks are growing so rapidly.

Indonesia, there is strong growth of sharia banking industry because of the vast majority of its Muslim population (Oxford Business Group, 2008). It was proven by a survey that was conducted by Bahrain Monetary Agency in 2004 which stated that the number of sharia banking institutions have been strong. It has been shown that during the period of 1997 to 2004, the number of sharia banking were dramatically increased from 176 to 267 respectively, operating in 60 countries around the world (Bahrain Monetary Agency, 2004). With a growth rate of $15 \%$ per year, sharia banking industry is the fastest growing sector in Muslim countries. Additionally, sharia banking in Indonesia has been showed a significant growth, with a growth rate of $2.2 \%$ (Suhendi and Indriastuti, 2014). 
According to Dusuki and Abdullah, (2007), the concept of the sharia reflects the holistic view of Islam, which is a complete and integrated code of life encompassing all aspects of life. It is for individual or social, both in this world and the Hereafter. The sharia's content consists of three main elements: (1) the Aqidah that discuss belief and faith; (2) the Akhlaq that discuss morality and ethics; and (3) the Fiqh or legal rulings governing the acts of human beings. Fundamental aspects, such as the aqidah and akhlaq, are not subject to change; however, the fiqh or legal rulings may change and vary according to time (Dusuki and Abdullah, 2007; Siwar and Hossain, 2009). Related with holistic view of sharia law, the function in the social role of sharia banks that entails social justice and accountability, requiring the banks to disclose social responsibilities information or as known as corporate social responsibility (Paino, Bahari and Bakar, 2011).

Corporate social responsibility (CSR) is an organization's commitment to conduct its business economically, socially and environmentally sustainable manner whilst balancing the interest of a diverse range of stakeholders (Khatun and Alautiyat, 2012). In Indonesia the disclosure of CSR is compulsory for certain enterprise criteria as mentioned in the Act No. 40/2007 on "Corporate" article 74. In addition the company is obliged to conduct CSR activities, the company is also obliged to disclose in the annual report as mentioned in Law No. 40/2007 on "Corporate" Article 66 paragraph (2). Thus, business entities in Indonesia inevitably are obliged to do CSR programs. If the CSR programs are not implemented, the government can impose penalties in accordance with the provision of applicable law.

In Islamic banking area, the position of Islamic Banking Institution (IBI) as one corporation of the area of finance that has been operating either nationally or internationally is obliged to be the pioneer of finance institution in carrying out CSR programs based on Islamic values. Related to the need of social responsibility's disclosure in sharia banking, currently there are discussions about the Islamic Social Reporting Index (ISR). ISR index contains a compilation of items CSR standards set by AAOIFI (Accounting and Auditing Organization for Islamic Financial Institutions), which was then developed further by the researchers regarding CSR items that should be disclosed by an Islamic entity. ISR index is believed to be the first step in terms of CSR disclosure standards in accordance with the Islamic perspective (Accounting and Auditing Organization for Islamic Financial Institutions, 2010).

Several previous researches show that the disclosure of CSR is influenced by company size and profitability. However, there are various findings and conclusions regarding each factor and its influence with the disclosure of CSR (Patten, 1991; Roberts, 1992; Hackston and Milne, 1996; Hasibuan, 2001; Sembiring, 2003; Gray, 2006). Besides, there are limited researches on disclosure of CSR in Islamic or sharia banking industry. Therefore, there is further need to examine the variable factors influencing the CSR disclosure in Islamic or sharia banking. Based on the explanations above, this research will analyze the factors influencing the disclosure of CSR in the sharia banking industry in Indonesia during the period of 2010 until 2013 using the data from ISR index. In the end of the research, the results and findings can be useful for scholars, practitioners, or government to give complete understanding on CSR disclosure specifically on Islamic banking institutions.

\section{Literature Review and Hypotheses Development}

\section{Sharia Banking}

Sharia or Syara' is the Arabic means law that was written or directly told according to Quran and Sunnah (Ullah and Jamali, 2010). According to the survey held by (Song and Oosthuizen, 2014), shariah law imposes a set of ethics that militates against exploitation, and prohibits involvement in activities that are considered morally distasteful, such as drugs, alcohol, prostitution, and games of chance. Islamic or sharia banking is using sharia law to practice all of banking activities and services which are free from usury or riba. 
In Indonesia, the term bank syariah (sharia banking) or bank Islam (Islamic banking) is not founded in Law No. 7/1992; there is only a phrase 'bank which is based on profit and loss sharing principle' to indicate the activities of a sharia bank although it has described the existence of sharia bank activities. However, the term, 'a bank which is based on profit and loss sharing principle' has not accommodated all kinds of activity and product patterns of a sharia bank. Besides products, sharia bank also conduct deposit, buy and sells, hires, and many more services which are permitted by sharia principle (Ascarya, 2007).

For these reasons, Ahmad and Hassan, (2007) have contended that sharia banks' obligations towards society are greater than those of conventional banks for the following three main reasons:

1. a sharia bank has a certain philosophical mission to achieve. According to Islamic principles, Allah is the creator and ultimate owner of all resources. Humans and institutions have a vicegerency role to play in society. Therefore, Islamic banks are not free to do as they wish, rather they have to integrate moral values with economic action.

2. a sharia bank must provide financing service to those who have talent and expertise, thereby strengthening the economic foundations of society.

3. a sharia bank should aim to create harmony in society based on the Islamic concept of sharing and caring in order to achieve economic, financial and political stability (Ahmad and Hassan, 2007).

Therefore the activities and operations of Islamic banks are not only based on government rules and regulations but, at the same time, must comply with the sharia law. Any activities that contradict with Islamic values and principles must be avoided. Thus, Islamic banks should not invest in companies that violate human rights and damage the natural environment (Ullah and Jamali, 2010). Moreover, Islamic banks are not allowed to finance any enterprise involved in activities relating to pork, pornography, tobacco, gambling, and alcoholic liquor (Nathan and Ribire, 2007).

\section{Corporate Social Responsibility Disclosure}

The concept of corporate social responsibility (CSR) now encourages business to engage personal corporate interest with community interest (Parker, 2005). CSR defined by Parker (2005) as the progression of business in negotiating their responsibility in society. He also stated,"...corporations engage in CSR activities for many reasons". Disclosure of social responsibility, or commonly referred as corporate social reporting is a process of communicating the social influences on the environment and economic measures in the company of certain groups in society and on society as a whole (Gray, Owen and Maunders, 1987).

There are a variety of media or documents for CSR, which includes: advertisements or articles published providing a detail company's activities; annual reports; booklets or leaflets to address the social activities of the company; CD reports; community reports; environmental reports; labelling of products to promote environmental and other concerns; press releases; the annual reports produced at interim dates; and video tapes and Websites. In this study, the researcher used annual reports as the main source of data (Jenkins \& Yakovlena, 2005).

\section{Islamic Social Reporting Index}

(Haniffa and Hudaib, 2006) emphasized that the conceptual framework for Islamic accounting should be based on the sharia as it was supported by the objectives of Islamic accounting as follows: To assist in achieving socio-economic justice (al-falah) and recognize thefulfillment of obligation to Allah, society and individuals concerned, by parties involved in the economic activities viz. accountants, auditors, managers, owner, government, etc as a form of worship.' 
Based on following reasons, Accounting and Auditing Organization for Islamic Financial Institutions (AAOIFI) set several items that should be included in CSR specifically for sharia banks (Accounting and Auditing Organization for Islamic Financial Institutions, 2010). The following ISR Index used in this research are:

1. Financing and Investment

a. Riba (interest-free/usury)

b. Gharar (uncertainty)

c. Zakat (tax)

d. Bad debts written off

e. Current Value Balance Sheet

f. Value Added Statement

2. Product and Services

a. Green Product

b. Halal Status Product

c. Quality and Safety of product

d. Customer Complaint

3. Employee

4. Society

5. Environment

6. Corporate governance

\section{Company Size}

Basically company size is divided into 3 categories which are big company, medium company, and small company (Suwito and Herawaty, 2005). The company size is one of the variables used to explain the variation of disclosures in annual reports (Adawiyah, 2013). The greater of company size, usually the greater availability of company to investor in decison-making in company (Siregar and Utama, 2006). The number of shareholders indicates if the company requires more disclosure due to the demands of shareholders because they believe corporations have the power to help out the entire community, environment, and humanity (Stoll, 2008).

The company with high size shows that it already is on the top or has reached the "maturity". It means the company has the positive cash flow is considered to have the good long-term prospect. Besides that, the company performs in the stable condition and more profitable compared to companies with small total asset because it is be able to cultivate asset effectively and efficiently (Rifan, 2015). The greater a company also the greater it will be highlighted by stakeholders. In such conditions the company requires a larger effort to gain legitimacy of stakeholders in order to create social values alignment of activities with the existing norms of behavior in society. Therefore, the larger the company will be more concerned to reveal more extensive information. (Anggraini, 2006) had the different assumption about the result. They conclude that company size did not influence to disclosure of CSR.

$\mathrm{H}_{1}$ : Company Size has a significant positive influence to disclosure of CSR

\section{Profitability}

Profitability is the company's ability to generate profits by using the resources of the company, such as assets, capital or sales (Sudana, 2009). Profitability is the important thing for all companies, without profit companies will face the diffficulty to gain capital from external. The underlying cause of a positive relation between social disclosure policy and profitability is management's knowledge. Managers that have the knowledge to make their companies profitable also have the knowledge and understanding of social responsibility (Belkaoui and Karpik, 1989). This might explain the higher levels of CSR disclosure is done by profitable companies. Relationship between CSR and profitability of the company has been postulated to reflect the view that social sensitivity requires 
the same managerial style as necessary to be able to make the profitable company (Hackston and Milne, 1996).

Relationship between profitability of companies with social responsibility disclosure the company has been postulated (basic assumption) to reflect the view that social reaction requires managerial style. Thus, the higher the level, the greater the company's profitability disclosure of social information (Hackston and Milne, 1996; Anggraini, 2006). Profitability has positive influence to disclosure of CSR, so the greater profitability produced by company, the larger information disclosed in annual report. Company with high profitability should be regularly in doing CSR activities (Nur and Priantinah, 2012).

$\mathrm{H}_{2}$ : Profitability has a significant positive influence to disclosure of CSR

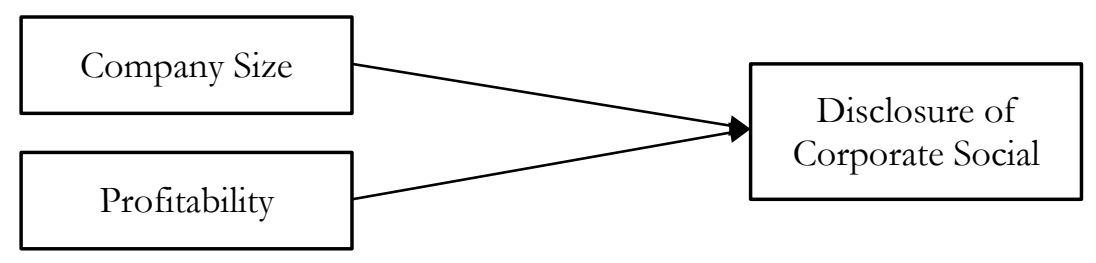

Figure 1. Conceptual Framework

\section{Research Methods}

\section{Sample}

The population of this research is sharia banks in Indonesia. To conduct this research, the researcher used data taken from annual report that have already been published by Sharia banks 2010-2013. Sample taken in this research is using purposive sampling method. The samples included in sharia banking are: BNI Sharia Bank, BRI Sharia Bank, Maybank Sharia Bank of Indonesia, Mega Sharia Bank of Indonesia, Muamalat Bank of Indonesia, Bukopin Sharia Bank, Mandiri Sharia Bank, Victoria Sharia Bank, Panin Indonesia ShariaBank, Bank BCA Sharia Bank, BJB Sharia Bank.

Table 1. The Selection of Research Sample

\begin{tabular}{clc}
\hline No. & \multicolumn{1}{c}{ Sample Criteria } & Total \\
\hline 1. & Sharia Banks in Indonesia for period 2010 - 2013 & 13 \\
2. & Sharia Bank that did not publish their annual report & $(2)$ \\
3. & Sharia Bank that did not have positive income & $(0)$ \\
4. & Sharia Bank that has not complete data related to the variable used by researcher & $(0)$ \\
5. & Sharia Bank that did not diclose the Corporate Social Responsibility & $(0)$ \\
\hline & Total & 11 \\
\hline
\end{tabular}

\section{Sample}

Data used in this research were secondary data which are annual report published in 2010-2013 annually. Source of data are books related to the topic of this research and internet sources. In addition to this, scholarly articles from academic journals, relevant text books, and other internet sources were also used.

\section{Research Equation}

For testing hypotheses, this study uses a statistical method of multiple linear regressions with a model as follows:

$\mathrm{CSRD}_{\text {it }}=\alpha+\beta_{1} \mathrm{CS}_{\mathrm{it}}+\beta_{2} \mathrm{ROE}_{\mathrm{it}}+\mathrm{\epsilon}$

with expectation: $\beta 1>0, \beta 2<0, \beta 3>0$ and the descriptions of: 


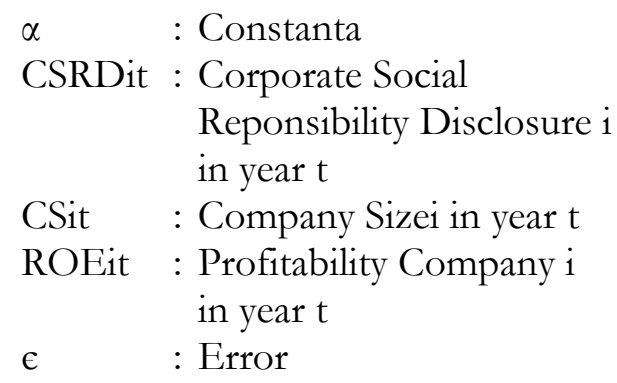

\section{Research Variables Definition and Measurement}

In this study, the dependent variable used is disclosure of CSR. It is to measure how far corporate disclosure of sharia banks have complied with the principles laid down in AAOIFI. This approach to count ICSR basically use the dichotomy approach which is the items of CSR will get 1 if there is the disclosure of instrument, and will get 0 if there is no disclosure of instrument. The next step is making the total of each score for each company. In this research, the independent variables are company size and profitability.

$$
\operatorname{CSRD}=\frac{\sum X i j}{38}
$$

ij $=$ dummy variable: $1=$ if the item is expressed; $0=$ if the item is not expressed.

$\mathrm{Nj}=$ the total item of company, $\mathrm{nj} \leq 38$

\section{Results}

Data analysis that used in this research are descriptive analysis, classical assumption test, normality test and hypothesis test. Multiple regression analysis is used to test hypothesis by using computer program of SPSS (Statistical Product and Service Solution) 21.0 and further discussions are provided in the last part of this chapter.

\section{Descriptive Analysis}

Descriptive statistics is used to observe the characteristics of samples that are used in a research. The data indicated by the minimum and maximum values, the average/mean and standard deviation of the research variables. The detailed sample can be seen in Table 2 . The table above illustrates the description of the variables used in this study. The minimum is the smallest value of a series of observations, while the maximum is the largest value of a series of observations. The mean is the sum of all data values divided by the number of data, while the standard deviation is the root of the sum of the squares of the difference between the value of the data with the mean divided by the average number of data.

Table 2. Descriptive Statistics

\begin{tabular}{|c|c|c|c|c|}
\hline & $\mathrm{N}$ Min & Maxi & Mean & Std. Dev. \\
\hline CSRD & 44,50 & 87 & ,7107 & ,10319 \\
\hline CS & 4411,50 & 14,00 & 13,7 & 61976 \\
\hline ROE & $44-3,26$ & 57,96 & 7,9352 & 11,43893 \\
\hline Valid N & 44 & & & \\
\hline
\end{tabular}

Based on Table 2, the results of analysis using descriptive statistics on the disclosure of Corporate Social Responsibility (CSRD) by looking at the number of items the disclosure of Corporate Social Responsibility (CSRD) by the company, it showed a minimum value of 0.50 , the maximum value of 0.87 with a mean/average of 0.710 and a standard deviation of 0.103 . From the 
result, CSRD variable has a small range with the minimum value and the maximum value from 44 samples. It also shows that standard deviation is greater than the mean. This result describes that the dispersion of data is not clustered around the average value calculated, and it can be concluded that the sample and population have no similarity. It meant that data are heterogeneous or the value of sample and population is distributed randomly and it can be concluded that the sample have variation of data. Corporate Social Responsibility Index was calculated with 38 items resulted mean of $71,07 \%$. It showed that annual report in one period, the company has disclosed 27 items about social disclosure that have been done.

Overall there is no sharia banks that perfectly establish all the items of ISR index. It is because sharia bank did not run the activities that actually it might be, for example gharar. This is also because the existence of items that sharia bank obviously did not do that kind of activity such as producing green product and take care of endangered wildlife.

Results of analysis using descriptive statistics to Company Size (CS) by calculating the log of the total assets showed a minimum value of 11,50 or Rp336.676.000.000,- and a maximum value of 14 or Rp32.481.873.142.495,- with an average of 13,7 or Rp11.834.839.775.678,- and a standard deviation of 0.6 or Rp16.894.383.886.378,-. From the result, the company size variable has a small range with the minimum value and the maximum value from 44 samples. It also showed that standard deviation is greater than the average. This result describes that the dispersion of data is not clustered around the average value calculated, and it can be concluded that the sample and population have no similarity. It means that data are heterogeneous or the value of sample and population is distributed randomly and it can be concluded that the sample have variation of data. The greater the asset, the greater sources of asset owned by company, so there is possibility the company will increase the source of disclosure that the company can delivered in annual report.

Results of analysis using descriptive statistics on profitability (ROE) was calculated from the ratio of net income after tax and total equity equal to $-3.26 \%$ indicates a minimum value or company loss, maximum value indicate that the companies were able to produce profit as much as $57.96 \%$ with an average of $7.93 \%$ and a standard deviation of $11,43 \%$. It has a big range between the minimum values. It also showed that standard deviation is below the average. This result describes that the dispersion of data is clustered around the average value calculated, and it can be concluded that the sample and population have similarity. It means that data are homogeneous or the value of sample and population is distributed not randomly and it can be concluded that the sample does not have variation of data.

\section{Classical Assumption}

The normality test is done by looking at the Normal P Plot statistical test. Kolomogorov Smirnov nonparametric statistical test is used to test the normality of residuals in this study. The distribution data is normal if the asymptotic significance is greater than 0.05 or $5 \%$. The result of Kolomogorov Smirnov test is described in Table 3.

Table 3. One-Sample Kolmogorov-Smirnov Test

\begin{tabular}{lll}
\hline & & ICSR \\
\hline $\mathrm{N}$ & & 44 \\
\hline Normal & Mean &, 7050 \\
Parameters ${ }^{\mathrm{a}, \mathrm{b}}$ & Std. Deviation &, 10868 \\
\hline \multirow{2}{*}{ Most Extreme } & Absolute &, 112 \\
Differences & Positive &, 082 \\
& Negative &,- 112 \\
\hline Kolmogorov-Smirnov Z &, 744 \\
\hline Asymp. Sig. (2-tailed) &, 637 \\
\hline
\end{tabular}


Based on the result of normality test in table 4.2 above, it showed that asymptotic significance is 0.637 or $63.7 \%$, which means the result is greater than 0.05 or $5 \%$. Therefore, it can be concluded that the distribution of data is normal.

Multicollinearity test can be performed by analyzing the calculation of the value of tolerance and the Variance Inflating Factor (VIF). If the VIF value $>10$ and tolerance value $<10 \%$ then the regression model multicollinearity occurs. Meanwhile, if the VIF value $<10$ and tolerance value $>$ $10 \%$ then there is no multicollinearity (Ghozali, 2005). The result of multicollinearity test can be shown in Table 4.

Table 4. Collinearity Statistics

\begin{tabular}{lll}
\hline Constant & Tolerance & VIF \\
\hline CS &, 903 & 1,107 \\
ROE &, 903 & 1,108 \\
\hline
\end{tabular}

Table 4 shows that there is no multicollinearity in all of independent variables that is used in the regression model. It can be seen from the tolerance value $>10 \%$ for variable of company size and profitability. While the value of VIF in all of independent variable of company size and profitability is $<10$.

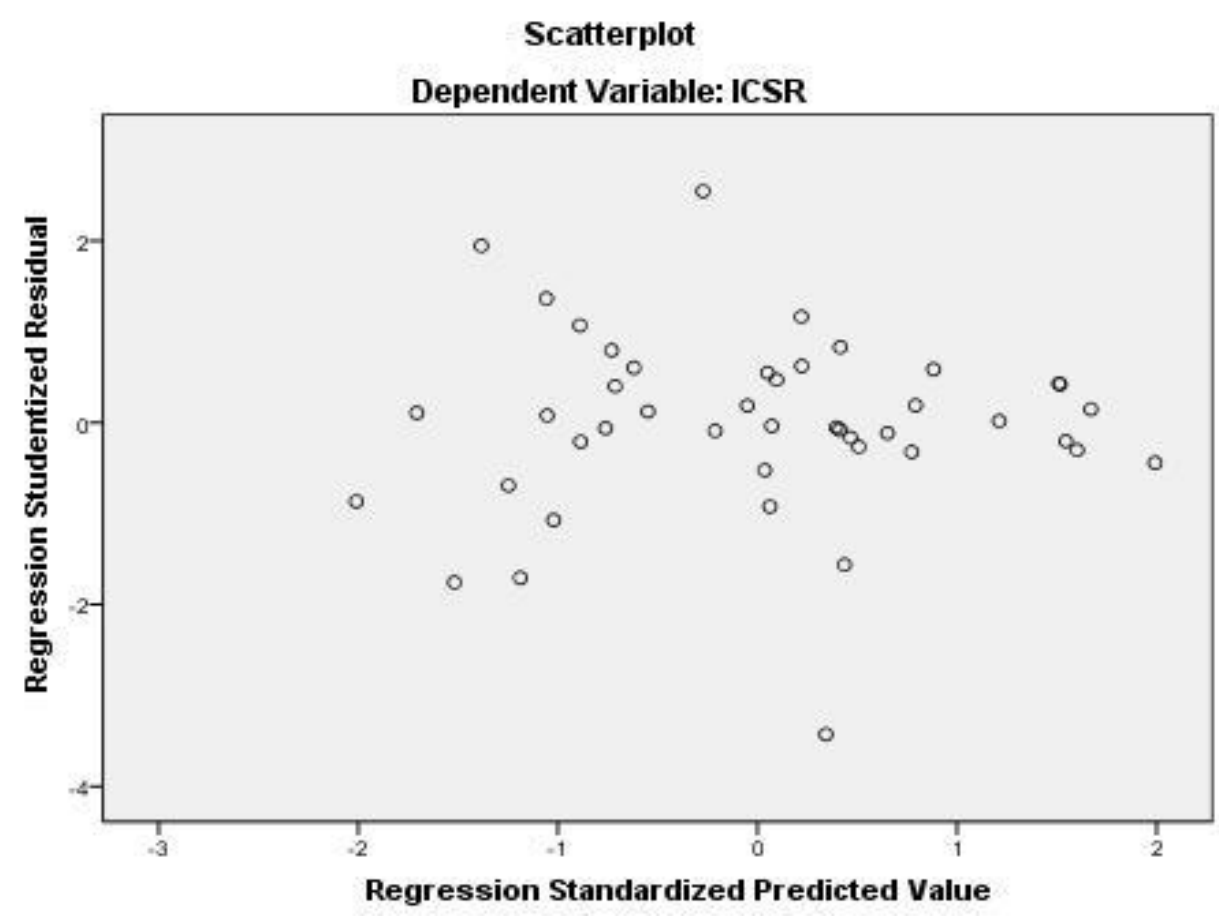

Figure 2. Scatter Plot

Heteroscedasticity test shows the error or residual model that has no constant variance from one observation to another observation. The heteroscedasticity test in this research was based on scatter plot. The testing was to identify a certain pattern of points on scatter plot by looking at the particular pattern. There is heteroscedasticity if no points or dots form an irregular pattern (wavy, widened, and narrowed). In contrast, there is no heteroscedasticity if no clear pattern in the graphs and the data are randomly distributed and the points spreading above and below 0 on the y-axis.

Based on the scatter plot in Figure 2, the points are spread randomly, do not form specific clear pattern, and the points spreading above and below the y-axis. It can be concluded that there are no symptom of heteroscedasticity in regression models. Autocorrelation test is to test whether 
the linear regression model has a correlation between the errors in period $t$ with the offense in period $\mathrm{t}-1$. The researcher used Durbin-Watson test to identify whether there is autocorrelation or not in the regression model.

The result of autocorrelation test using Durbin-Watson can be found in table 4.4, using the significant level (á) of $5 \%$ with the amount of sample (n) is 44 and there are three variables $(k=3)$. From Durbin-Watson table (á; $; \mathrm{n}=0.05 ; 3 ; 44)$ it was found that the value of DL is 1,383 and the value of DU is 1,666. Based on Table 5, the result of Durbin-Watson test is 1,674. The value of Durbin-Watson is located between the upper limit and upper bound (du) and (4-du) which means $\mathrm{du}<\mathrm{dw}<4-\mathrm{du}(1.666<1.674<2,334)$. Therefore it can be concluded that there is no autocorrelation in the regression model.

Table 5. Model Summary

\begin{tabular}{lllll}
\hline R & R Square & Adjusted & Std. & Durbin- \\
R Square & Error & Watson \\
\hline, $867^{\mathrm{a}}$ &, 751 &, 732 &, 05623 & 1,674 \\
\hline
\end{tabular}

\section{Hypothesis Test}

Regression analysis is basically done with the aim to estimate and predict the average or population or the average value of the dependent variable based on the value of the independent variables. Table 6 showed the results of multiple regression analysis using the formula:

CSRDit $=-1,161+, 146($ CSit $)+8,056 \mathrm{E}-005$ (ROEit)

The regression equation above shows that the Company Size (CS) and profitability (ROE) have positive coefficient. Constanta is - 1,161, it means if Company Size and Profitability is 0 , so that the disclosure of CSR is $-1,161$. Regression Coefficient of Company Size is ,146. It means that every increasing one unit of total asset will increase the disclosure of CSR as much as 0,146 while the other variables are considered unchanged. Regression Coefficient of Profitability is $8,056 \mathrm{E}$ 005. It means every increasing $1 \%$ of profitability will increase the disclosures of CSR as much as $8,056 \mathrm{E}-005$ or $0 \%$ and other variables are considered unchanged.

Table 6. Multiple Regression Analysis

\begin{tabular}{lccccc}
\hline \multicolumn{7}{c}{ Unstandardized Coefficients } & \multicolumn{2}{c}{$\begin{array}{c}\text { Standardized } \\
\text { Coefficients }\end{array}$} \\
\hline \multicolumn{1}{c}{ Model } & $\mathrm{B}$ & Std. Error & Beta & t & Sig \\
\hline 1 (Constant) & $-1,161$ &, 183 & & $-6,356$ &, 000 \\
CS &, 146 &, 015 &, 831 & 10,014 &, 000 \\
ROE & $8,056 \mathrm{E}-005$ &, 001 &, 008 &, 102 &, 919 \\
\hline
\end{tabular}

F value is aimed to show whether all the independent variables can fit in the regression model simultaneously have an influence towards dependent variable (Ghozali, 2005). The hypothesis will be testing a confidence level of $95 \%$ or significance level (á) of $5 \%$ or 0.05 . Table 7 shows the result of $\mathrm{F}$ test.

Table 7. ANOVA

\begin{tabular}{lccccc}
\hline \multicolumn{1}{c}{ Model } & Sum of Squares & Df & Mean Square & F & Sig. \\
\hline Regression &, 381 & 3 &, 127 & 40,219 &, $000^{\mathrm{b}}$ \\
Residual &, 126 & 40 &, 003 & & \\
Total &, 508 & 43 & & & \\
\hline
\end{tabular}


Table 7 presented that the result of $\mathrm{F}$ count is 40.219 and $\mathrm{p}$-value is 0.000 . It can be seen that $\mathrm{p}$-value is less than $0.05(0.000<0.005)$. Therefore, it can be concluded that the correlation coefficients statistically significant and fit with the regression model simultaneously and variable company size and profitability simultaneously have significant influence on disclosure of corporate social responsibility.

In order to test the influence of company size and profitability toward the disclosure of Corporate Social Responsibility, multiple regressions can be used and described. Hypothesis significance testing is done through regression coefficient of CS (Company Size) variable. Based on the result of t-test in Table 7 .

CS variable has significant positive influence to the disclosure of Corporate Social Responsibility. The coefficient of CS has value 0,146 with $t$-count value is 10,014 and $p$-value is 0,000 . It can be concluded that probability value is less than á (0.05), therefore Ho is rejected and $\mathrm{Ha}$ is accepted. It means there is significant positive influence of Company Size (CS) to the disclosure of Corporate Social Responsibility.

Based on the result of t-test in Table 7, profitability variable has no influence to the disclosure of Corporate Social Responsibility. The coefficient of profitability has value 8,056E-005 with t-count value is 0,102 and $\mathrm{p}$-value is 0,919 . It can be concluded that probability value is more than á (0.05), therefore Ho is accepted and $\mathrm{Ha}$ is rejected. It means there is no significant influence of profitability ratio (ROE) to the disclosure of Corporate Social Responsibility.

The coefficient of determination (R2) is a value that indicates how much the independent variables can explain the dependent variable. Coefficient of determination test results is shown in Table 6. It shows the coefficient of determination (R2) by considering the adjusted R square. It has the value of 0.732 or $73.2 \%$. It showed that the independent variables used in the regression models (company size and profitability) are able to explain its influence toward disclosure of Corporate Social Responsibility by $73,2 \%$, while the influence of $26,8 \%$ is explained by other factors that are not used in this research regression model.

\section{Discussion}

The result of multiple regression analysis on hypothesis 1 showed that the company size has significant influence on the disclosure of Corporate Social Responsibility. The coefficient of CS is positive and statistically significant $(\mathrm{p}=0.000)$, it means the hypothesis 1 is accepted. The result showed that Sharia Bank which have high total asset of company will result in a good disclosure of Corporate Social Responsibility. The results in this study supported the research conducted by (Belkaoui and Karpik, 1989; Hackston and Milne, 1996; Sembiring, 2003; Anggraini, 2006) who proved the influence of company size on the disclosure of corporate social responsibility

The result of multiple regression analysis on hypothesis 2 showed that the profitability ratio has no significant influence on the disclosure of Corporate Social Responsibility. The coefficient of profitability is positive and statistically insignificant $(\mathrm{p}=0,919)$. It means that hypothesis 3 is rejected. The result of this research does not support the study held by Anggraini (2006) that stated the higher level of profitability, the greater the disclosure of social information because of some possibility factors such as the proxy used, amount of samples, and the period of observation. Anggraini (2006) used net profit margin as the proxy. The other possible reason was because there is disclosure of CSR is not in line with the profitability in same period, but probably it is in line with the previous period probability (lagged profit).

\section{Conclusions}

Based on the statistical test, analysis, and discussion that have been done in the previous chapter, the results show company size has a significant influence on the disclosure of CSR. It is shown that large companies tend to disclose social responsibility with more information. Meanwhile, profitability did not have any significant influence on the disclosure of CSR. This showed that the 
company having high profitability did not indicate to have more social activities because it is considered to voluntarily report things that can interfere with information about the success of the financial statements. Therefore, it can be concluded that company size has an influence to the disclosure of CSR while the profitability does not have any influence to the disclosure of CSR.

The limitations of this study are this research only used two factors influencing disclosure of CSR in companies' annual report for 4 periods because of limitation of time and this research only use single source that comes from annual report. Research on the disclosure of CSR in the future is expected to provide a higher quality of research results, taking into account the suggestions below: add longer observation period and few other variables as factors that could influence the disclosure of CSR such as media exposure, environmental performance, managerial performance, and firm's reputation; it can use other collecting data technique, such as questionnaires or interviews to a company or government agency to find out more information on the disclosure of CSR.

\section{References}

Accounting and Auditing Organization for Islamic Financial Institutions (2010) Accounting, Auditing and Governance Standards for Islamic Financial Institutions.

Adawiyah, R. (2013) Pengarub Tipe Industri, Ukuran Perusahaan, Profitabilitas, dan Leverage Terhadap Pengungkapan Corporate Social Responsiility. Jakarta. Available at: http://repository.uinjkt.ac.id/dspace/bitstream/123456789/23845/1/Skripsi Ira.pdf.

Ahmad, A. U. F. and Hassan, M. K. (2007) 'Riba and Islamic Banking', Journal of Islamic Economics, Banking and Finance, 3(1), pp. 1-33.

Anggraini, F. R. R. (2006) 'Pengungkapan Informasi Sosial dan Faktor-Faktor yang Mempengaruhi Pengungkapan Informasi Sosial dalam Laporan Keuangan Tahunan (Studi Empiris pada Perusahaan-Perusahaan yang terdaftar Bursa Efek Jakarta)', in Simposium Nasional Akuntansi 9 Padang. Padang: Ikatan Akuntan Indonesia, pp. 1-21. Available at: https://repository.usd.ac.id/32801/1/4747_K-AKPM-24.pdf.

Arifin, M. and Nasution, B. (2015) 'The Dinamics Study of Regulations of Syariah Banking Indonesia', International Journal of Humanities and Social Science, 5(3), pp. 237-242. Available at: http://jurnal.umsu.ac.id/index.php/kumpulandosen/article/view/2670/pdf_634.

Ascarya (2007) Akad dan Produk Bank Syariah. Jakarta: Raja Grafindo Persada.

Bahrain Monetary Agency (2004) Babrain financial sector factfile.

Belkaoui, A. and Karpik, P. G. (1989) 'Determinants of the Corporate Decision to Disclose Social Information', Accounting, Auditing \& Accountability Journal, 2(1). doi: 10.1108/09513578910132240.

Dusuki, A. W. and Abdullah, N. I. (2007) 'Maqasid al-shari'ah Maslahah and Corporate Social Responsibility', The American Journal of Islamic Social Sciences, 24(1).

Ghozali, I. (2005) Aplikasi analisis multivariate dengan program SPSS. Semarang: Universitas Diponegoro.

Gray, R. (2006) Social, environmental and sustainability reporting and organisational value creation?, Accounting, Auditing \& Accountability Journal. doi: 10.1108/09513570610709872.

Gray, R., Owen, D. and Maunders, K. T. (1987) Corporate Social Reporting: Accounting and Accountability. London: Prentice-Hall International. 
Hackston, D. and Milne, M. J. (1996) 'Some determinants of social and environmental disclosures in New Zealand companies', Accounting, Auditing \& Accountability Journal, 9(1), pp. 77-108. doi: 10.1108/09513579610109987.

Haniffa, R. and Hudaib, M. (2006) 'Corporate Governance Structure and Performance of Malaysian Listed Companies', Journal of Business Finance Accounting, 33(7-8), pp. 1034-1062. doi: $10.1111 /$ j.1468-5957.2006.00594.x.

Hasibuan, M. (2001) Manajemen: Dasar, Pengertian, dan Masalah. Jakarta: Bumi Aksara.

Khatun, K. M. and Alautiyat, H. (2012) 'Corporate Social Responsibility: An Islamic Perspective', Corporate Social Responsibility: An Islamic Perspective, 2(3), pp. 415-433.

Nathan, S. and Ribire, Vi. (2007) 'From knowledge to wisdom: the case of corporate governance in Islamic banking', VINE: The journal of information and knowledge management systems, 37(4), pp. 471-483. doi: 10.1108/03055720710838533.

Nur, M. and Priantinah, D. (2012) 'Faktor-Faktor Yang Mempengaruhi Pengungkapan Corporate Social Responsibility di Indonesia (Studi Empiris Pada Perusahaan Berkategori High Profile Yang Listing Di Bursa Efek Indonesia', Jurnal Nominal, 1(2). doi: 10.21831/nominal.v1i2.996.

Oxford Business Group (2008) The Report Indonesia.

Paino, H., Bahari, A. B. and Bakar, R. A. (2011) 'Shariah, Social Responsibilities and Corporate Governance of the Islamic Banks in Malaysia', European Journal of Social Sciences, 23(3).

Parker, B. (2005) Introduction to Globalization and Business: Relationships and Responsibilities. Sage Publications. doi: 10.4135/9781446215869.

Patten, D. M. (1991) 'Exposure, legitimacy, and social disclosure', Journal of Accounting and Public Policy, 10(4). doi: 10.1016/0278-4254(91)90003-3.

Rifan, D. F. (2015) Pengarub Pengungkapan Corporate Social Responsibility dan Ukuran Perusabaan Terbadap Kinerja Keuangan (Studi Pada Perusahaan Pertambangan yang Listing di BEI Tabun 2010-2013). Bandar Lampung.

Roberts, R. W. (1992) 'Determinants of Corporate Social Responsibility: An Application of Stakeholder Theory, Accounting', Accounting, Organizations and Society1, 17(6). doi: 10.1016/0361-3682(92)90015-K.

Sembiring, E. R. (2003) 'Karakteristik Perusahaan dan Pengungkapan Tanggung Jawab Sosial : Studi Empiris Pada Perusahaan Yang Tercatat di Bursa Efek Jakarta', in Simposium Nasional Akuntansi VI. Ikatan Akuntan Indonesia.

Siregar, S. V. and Utama, S. (2006) 'Pengaruh Struktur Kepemilikan, Ukuran Perusahaan, dan Praktek Corporate Governanca Terhadap Pengelolaan Laba (Earnings Management)', Indonesian Journal of Accounting Research, 9(3). doi: 10.33312/ijar.161.

Siwar, C. and Hossain, M. T. (2009) 'An analysis of Islamic CSR concept and the opinions of Malaysian managers', Management of Environmental Quality, 20(290-298). doi: 10.1108/14777830910950685.

Song, I. and Oosthuizen, C. (2014) Islamic Banking Regulation and Supervision: Survey Results and Challenges. Available at: https://www.imf.org/external/pubs/ft/wp/2014/wp14220.pdf.

Stoll, M. L. (2008) 'Backlash Hits Business Ethics: Finding Effective Strategies for Communicating the Importance of Corporate Social Responsibility', Journal of Business Ethics, 78, pp. 17-24. doi: 10.1007/s10551-006-9311-2.

Sudana, I. M. (2009) Manajemen Kenangan: Teori dan Praktik. Surabaya: Universitas Airlangga Press. 
Suhendi, C. and Indriastuti, M. (2014) 'CSR Disclosure Evidance in Indonesia : Sharia and NonSharia Bank', South East Asia Journal of Contemporary Business, Economics and Law, 4(2).

Suwito, E. and Herawaty, A. (2005) 'Analisis Pengaruh Karakteristik Perusahaan Terhadap Tindakan Perataan Laba Yang Dilakukan Oleh Perusahaan Yang Terdaftar Di Bursa Efek Jakarta', in Simposium Nasional Akuntansi.

Ullah, S. and Jamali, D. (2010) 'Institutional Investors And Corporate Social ResponsibilityThe Role Of Islamic Financial Institutions', Islamic Financial Institutions and CSR, 6(1). doi: 10.1.1.579.8732. 